\title{
Break-apart interphase fluorescence in situ hybridization assay in papillary thyroid carcinoma: on the road to optimizing the cut-off level for RETIPTC rearrangements
}

\author{
Chiara Colato ${ }^{1}$, Caterina Vicentini ${ }^{2}$, Silvia Cantara ${ }^{3}$, Serena Pedron ${ }^{1}$, \\ Paolo Brazzarola ${ }^{4}$, Ivo Marchetti ${ }^{5}$, Giancarlo Di Coscio5, Marco Chilosi', \\ Matteo Brunelli ${ }^{1}$, Furio Pacini ${ }^{3}$ and Marco Ferdeghini ${ }^{1,6}$
}

${ }^{1}$ Department of Pathology and Diagnostics and ${ }^{2}$ ARC-NET Research Centre, University of Verona, Policlinico GB Rossi, Piazzale LA Scuro, 10, Piastra Odontoiatrica (II floor), 37134 Verona, Italy, ${ }^{3}$ Department of Internal Medicine Endocrinology, and Metabolism and Biochemistry, University of Siena, Siena, Italy, ${ }^{4}$ Department of Surgery and Oncology, University of Verona, Verona, Italy, ${ }^{5}$ Division of Surgical, Molecular and Ultrastructural, Section of Cytopathology, University Hospital of Pisa, Pisa, Italy and ${ }^{6}$ Nuclear Medicine Unit, University Hospital of Verona, Verona, Italy
Correspondence should be addressed to C Colato

Email

chiara.colato@

ospedaleuniverona.it

\begin{abstract}
Objective: Chromosomal rearrangements of the RET proto-oncogene is one of the most common molecular events in papillary thyroid carcinoma (PTC). However, their pathogenic role and clinical significance are still debated. This study aimed to investigate the prevalence of RET/PTC rearrangement in a cohort of BRAF WT PTCs by fluorescence in situ hybridization (FISH) and to search a reliable cut-off level in order to distinguish clonal or non-clonal RET changes.

Design: Forty BRAF WT PTCs were analyzed by FISH for RET rearrangements. As controls, six BRAFV600E mutated PTCs, 13 follicular adenomas (FA), and ten normal thyroid parenchyma were also analyzed.

Methods: We performed FISH analysis on formalin-fixed, paraffin-embedded tissue using a commercially available RET break-apart probe. A cut-off level equivalent to $10.2 \%$ of aberrant cells was accepted as significant. To validate FISH results, we analyzed the study cohort by qRT-PCR.

Results: Split RET signals above the cut-off level were observed in $25 \%$ (10/40) of PTCs, harboring a percentage of positive cells ranging from 12 to $50 \%$, and in one spontaneous FA (1/13,7.7\%). Overall, the data obtained by FISH matched well with qRTPCR results. Challenging findings were observed in five cases showing a frequency of rearrangement very close to the cut-off. Conclusions: FISH approach represents a powerful tool to estimate the ratio between broken and non-broken RET tumor cells. Establishing a precise FISH cut-off may be useful in the interpretation of the presence of RET rearrangement, primarily when this strategy is used for cytological evaluation or for targeted therapy.
\end{abstract}

\section{Introduction}

Papillary thyroid carcinoma (PTC) is the most prevalent form of thyroid cancers, accounting for $80 \%$ of all cases. It is characterized by genetic alterations leading to the activation of the MAPK signaling pathway. Together with $B R A F$ point mutations, RET gene rearrangements represent the two most common molecular events in PTC $(1,2,3)$.
The rearranged during transfection (RET) protooncogene maps to the long arm of chromosome 10 at band q11.2 and encodes for a transmembrane tyrosinekinase receptor involved in the control of cell differentiation, cell proliferation, and cell survival $(4,5)$. Oncogenic activation of the RET gene via chromosomal 
rearrangement is generally related to radiation exposure and young age (40-70\%), but may be found in nonradiated thyroid tumors and in adults $(20-40 \%)(6,7)$.

Moreover, a recent study has revealed that $18 \%$ of poorly differentiated thyroid carcinomas (PDTC) and 9\% of radioactive iodine (RAI) refractory-FDG-PET-positive PDTC harbored RET/PTC rearrangements (8).

These rearrangements (balanced inversions or translocations) derive from the fusion of the $3^{\prime}$ portion of the RET gene to the $5^{\prime}$ portion of several heterologous genes and create fusion proteins with transforming activity, as demonstrated in in vitro experiments and in transgenic mice models $(9,10,11,12)$.

To date, at least 13 different forms of RET rearrangement have been documented (13), with RET/PTC1 (consisting of the fusion of RET with the $H 4$ gene) and RET/PTC3 (consisting of the fusion of RET with the $R F G / E L E 1$ gene) being the most common $(2,14)$.

A wide range of prevalence of RET/PTC rearrangements in human PTC has been reported, ranging from 3\% in Saudi Arabia, 29-35\% in Italy, 40\% in Canada, to 85\% in Australia $(15,16,17,18)$, which can be attributed to ethnical and geographic variability as well as to different sensitivities of detection methods, tumor heterogeneity, age, and radiation exposure $(6,19,20,21,22,23,24$, $25,26,27,28,29,30,31)$. Indeed, non-clonal RET/PTC rearrangements have been found not only in PTC but also in $10-45 \%$ of follicular thyroid adenomas, oncocytic thyroid tumors, and Hashimoto's thyroiditis (30, 32, 33, $34,35,36,37,38,39)$.

The specificity of this rearrangement, as a marker of PTC, has been challenged, and its clinical significance is still under debate. Thus, finding a reliable and biologically relevant strategy for $R E T / P T C$ detection may have important clinical and diagnostic implications as the detection of RET/PTC has been offered as a diagnostic tool for PTC in the surgical and preoperative cytological material $(40,41$, $42,43,44,45)$. Moreover, the emergence of drugs that selectively inhibit RET kinase activity highlights the need of a better understanding of RET/PTC distribution within the tumor volume and of standardization of the detection methods for this rearrangement $(46,47,48,49)$. Interphase fluorescence in situ hybridization (FISH) represents the gold standard method for detecting gene rearrangements at the single-cell level and is the most sensitive mean for identifying and quantifying intratumoral genetic heterogeneity $(50,51,52)$.

The aim of this study was to test a new commercially available RET break-apart probe on formalin-fixed, paraffin-embedded (FFPE) samples, to investigate the

prevalence of $R E T / P T C$ in a cohort of BRAF WT PTCs, to search for a reliable cut-off level in an attempt to distinguish the clonal or non-clonal event of the RET rearrangements, and to explore whether RET/PTC may be a relevant pathogenic factor.

\section{Materials and methods}

\section{Samples collection}

Forty cases of BRAF WT PTC (31 sporadic; two familial, one familial adenomatous polyposis-associated PTC and six with history of exposure to external beam radiotherapy) were analyzed during the study.

The cases were selected from a consecutive series of 250 PTCs collected from 2003 to 2013 from the files of the Pathology Unit, University of Verona. Previously, all samples had been tested for BRAFV600E mutation status (Fig. 1). The histology of all tumor samples was confirmed independently by two pathologists (C C and M B) and classified according to the World Health Organization guidelines (53). As a control group, six BRAFV600E mutated PTCs and 13 follicular adenomas (FA) (12 sporadic and one with a history of exposure to external beam radiotherapy) were also tested for $R E T$ rearrangements (Fig. 1). BRAF WT tumor tissue samples were obtained from 37 patients; in three patients with multifocal disease we examined two neoplastic foci (Table 1 , cases $2 \mathrm{a}$ and $2 \mathrm{~b}$, $17 \mathrm{a}$ and 17b, 20a and 20b). Moreover, one case of $B R A F V 600 \mathrm{E}$ mutated PTCs (Table 1 , case $18 \mathrm{~b}$ ) belonged

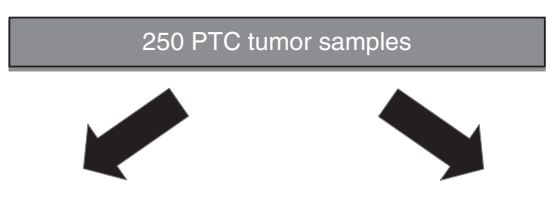

210 PTC BRAFV600E (84\%)

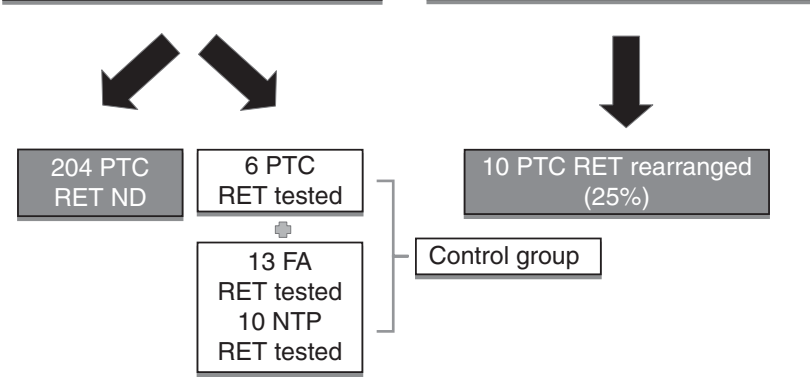

Figure 1

Schematic representation of the study design. ND, not determined. 
Table 1 Clinico-pathological and molecular findings in PTC.

\begin{tabular}{|c|c|c|c|c|c|c|c|c|c|c|c|}
\hline Samples & $\begin{array}{c}\text { Age } \\
\text { (years) }\end{array}$ & Gender & $\begin{array}{l}\text { Radiation } \\
\text { exposure }\end{array}$ & $\begin{array}{l}\text { Diameter } \\
(\mathrm{mm})\end{array}$ & Histological variant & Thyroiditis & Stage & $\begin{array}{c}\text { Split RET } \\
\text { signals } \\
(\%)\end{array}$ & $\begin{array}{l}\text { RETIPTC } \\
\text { rearrange- } \\
\text { ment }\end{array}$ & $\begin{array}{l}\text { BRAF- } \\
\text { V600E } \\
\text { status }\end{array}$ & $\begin{array}{l}\text { Follow- } \\
\text { up }\end{array}$ \\
\hline 1 & 49 & $\mathrm{~F}$ & No & 4 & Oncocytic & No & I & 2 & Negative & WT & NED \\
\hline $2 a$ & 15 & $\mathrm{~F}$ & No & 12 & Classical & Yes & I & 2 & Negative & WT & BPD \\
\hline $2 b$ & 15 & $\mathrm{~F}$ & No & 5 & Classical & Yes & I & 0 & Negative & WT & BPD \\
\hline 3 & 26 & $\mathrm{~F}$ & No & 16 & Follicular & Yes & I & 6 & Negative & WT & NED \\
\hline 4 & 44 & $\mathrm{~F}$ & No & 15 & Follicular & No & I & 4 & Negative & WT & NED \\
\hline 5 & 36 & $\mathrm{~F}$ & No & 24 & Follicular & No & I & 4 & Negative & WT & NED \\
\hline 6 & 27 & $\mathrm{~F}$ & No & 10 & Follicular & Yes & I & 6 & RET/PTC1 & WT & NED \\
\hline 7 & 19 & $\mathrm{M}$ & No & 40 & Follicular & No & I & 3 & Negative & WT & NED \\
\hline 8 & 29 & $\mathrm{~F}$ & No & 40 & Tall Cell & Yes & I & 4 & Negative & WT & BPD \\
\hline 9 & 35 & $\mathrm{~F}$ & No & 20 & Cribriform morular & Yes & I & 6 & Negative & WT & NED \\
\hline 10 & 20 & $\mathrm{~F}$ & No & 35 & Follicular & No & I & 2 & Negative & WT & NED \\
\hline 11 & 34 & $\mathrm{~F}$ & No & 8 & Classical & Yes & I & 2 & Negative & WT & NED \\
\hline 12 & 18 & $\mathrm{~F}$ & No & 8 & Classical & No & I & 9 & RET/PTC3 & WT & NED \\
\hline 13 & 37 & $\mathrm{~F}$ & No & 10 & Follicular & Yes & I & 4 & Negative & WT & NED \\
\hline 14 & 36 & $\mathrm{~F}$ & No & 38 & Follicular & No & I & 2 & Negative & WT & NED \\
\hline 15 & 24 & M & No & 45 & Follicular & No & I & 10 & Negative & WT & BPD \\
\hline 16 & 29 & $\mathrm{~F}$ & No & 20 & Follicular & Yes & I & 10 & RET/PTC1 & WT & NED \\
\hline $17 a$ & 55 & $\mathrm{~F}$ & No & 9 & Follicular & Yes & II & 6 & Negative & WT & NED \\
\hline $17 \mathrm{~b}$ & 55 & $\mathrm{~F}$ & No & 22 & Follicular & Yes & II & 8 & Negative & WT & NED \\
\hline $18 a$ & 43 & $\mathrm{~F}$ & No & 10 & Cribriform morular & Yes & III & 4 & Negative & WT & NED \\
\hline 19 & 65 & $\mathrm{M}$ & No & 45 & Follicular & No & III & 10 & Negative & WT & NED \\
\hline $20 a$ & 53 & $\mathrm{~F}$ & No & 14 & Follicular & Yes & III & 8 & Negative & WT & BPD \\
\hline 21 & 69 & $\mathrm{~F}$ & No & 48 & Solid & No & III & 0 & Negative & WT & PD \\
\hline 22 & 57 & M & No & 55 & Solid & No & IVa & 4 & Negative & WT & BPD \\
\hline 23 & 75 & $\mathrm{~F}$ & No & 60 & $\begin{array}{l}\text { Classical with minor } \\
\text { poorly differen- } \\
\text { tiated com- } \\
\text { ponent }\end{array}$ & No & IVc & 5 & Negative & WT & Dead \\
\hline 24 & 36 & M & No & 35 & Follicular & No & I & 48 & RET/PTC1 & WT & SpeD \\
\hline 25 & 11 & $\mathrm{~F}$ & No & 45 & Solid & No & I & 50 & RET/PTC3 & WT & SpeD \\
\hline 26 & 37 & $\mathrm{~F}$ & No & 11 & Solid & Yes & I & 13 & RET/PTC1 & WT & BPD \\
\hline 27 & 27 & $\mathrm{~F}$ & No & 11 & Classical & Yes & I & 28 & RET/PTC1 & WT & NED \\
\hline 28 & 39 & $\mathrm{~F}$ & No & 25 & Classical & No & I & 20 & RET/PTC1 & WT & SpeD \\
\hline 29 & 34 & $\mathrm{~F}$ & No & 17 & Diffuse sclerosing & Yes & I & 26 & RET/PTC1 & WT & NED \\
\hline 30 & 36 & $\mathrm{~F}$ & No & 50 & Follicular & Yes & I & 50 & RET/PTC1 & WT & NED \\
\hline 31 & 11 & $\mathrm{~F}$ & No & 20 & Diffuse sclerosing & Yes & I & 18 & RET/PTC1 & WT & $\begin{array}{l}\text { Lost at } \\
\text { follow } \\
\text { up }\end{array}$ \\
\hline $20 \mathrm{~b}$ & 53 & $\mathrm{~F}$ & No & 20 & Follicular & Yes & III & 12 & RET/PTC1 & WT & BPD \\
\hline 32 & 26 & $\mathrm{M}$ & Yes & 22 & Classical & No & I & 30 & RET/PTC1 & WT & SpeD \\
\hline 33 & 38 & $M$ & Yes & 8 & Follicular & No & I & 0 & Negative & WT & NED \\
\hline 34 & 8 & $\mathrm{~F}$ & Yes & 6 & Classical & No & I & 4 & Negative & WT & BPD \\
\hline 35 & 29 & $\mathrm{~F}$ & Yes & 9 & Classical & No & I & 1 & Negative & WT & NED \\
\hline 36 & 36 & $M$ & Yes & 3 & Classical & No & I & 0 & Negative & WT & $\begin{array}{l}\text { Dead of } \\
\text { other } \\
\text { disease }\end{array}$ \\
\hline 37 & 49 & $\mathrm{M}$ & Yes & 7 & Classical & No & I & 2 & Negative & WT & NED \\
\hline 1 & 40 & $\mathrm{~F}$ & No & 16 & Classical & No & I & 4 & Negative & V600E & NED \\
\hline 2 & 30 & $M$ & No & 20 & Classical & Yes & I & 2 & Negative & V600E & NED \\
\hline 3 & 32 & $\mathrm{~F}$ & No & 6 & Classical & No & I & 8 & Negative & V600E & BPD \\
\hline 4 & 29 & $\mathrm{~F}$ & No & 7 & Classical & No & I & 6 & Negative & V600E & NED \\
\hline 5 & 53 & $\mathrm{~F}$ & No & 7 & Classical & No & I & 6 & Negative & V600E & NED \\
\hline $18 \mathrm{~b}$ & 43 & $\mathrm{~F}$ & No & 8 & Follicular & Yes & III & 5 & Negative & V600E & NED \\
\hline
\end{tabular}

NED, not evidence of disease; SPeD, structural persistence disease; BPD, biochemical persistence disease; PD, progression disease. 
to a patient included in the BRAFV600E WT group (Table 1, case 18a). Concerning the cases exposed to external irradiation (six PTC and one FA), the patients received radiation therapy for primary cancer (one thymoma, one brainstem glioma, three leukemias, one cerebellar astrocytoma, one rhabdomyosarcoma of the neck), during childhood (four patients) or as adults (three patients). The radiation dose was available only for one patient and amounted to 18 Gy (Table 1, case 35). Regarding the PTC subset, the tumor latency was as follows: 7, 3, 6, 25, 16, and 45 years respectively (Table 1, cases 32-37); for the FA, the latency was 25 years (Table 2 , case 1 ).

The medical records of each patient ( 42 with PTC: 37 WT, and five $B R A F$-mutated and 13 with FA) were reviewed to obtain clinical and demographic data. Informed consent was obtained from all patients, as per the recommendations of our Ethics Committee.

\section{Fluorescence in situ hybridization}

To evaluate RET/PTC rearrangements (either inversion $10 \mathrm{q} 11.2$ or translocations), FISH was performed using the REPEAT-FREE POSEIDON RET (10q11) break-apart probe (Kreatech Diagnostics, Amsterdam, The Netherlands) on FFPE samples.

This commercial probe is designed as a dual-color probe where the two regions across the break-point, the proximal and the distal region to RET (10q11), are directlabeled with Platinum Bright 550 and with Platinum Bright 495 respectively.

The FISH procedure was performed following Kreatech's protocol with modifications designed in our laboratory, in particular regarding the tissue digestion and the hybridization times (54).

In brief, $3 \mu \mathrm{m}$ thick FFPE tissue sections were mounted on positively charged slides and air dried. Targeted tumor areas were circled with a pen, after review of the corresponding hematoxylin and eosin (H\&E) stained slide by a pathologist.

The sections were deparaffinized with two 10-min washes in xylene, hydrated in 100, 85, and 70\% ethanol solutions for $10 \mathrm{~min}$ each, rinsed in distilled water for $10 \mathrm{~min}$, fixed in methanol:acetic acid 3:1 for $10 \mathrm{~min}$ and air-dried. Next, the sections were treated in a $2 \times$ SSC solution for $15 \mathrm{~min}$ at $37^{\circ} \mathrm{C}$, and then dehydrated in consecutive 70,85 , and $100 \%$ ethanol solutions for $1 \mathrm{~min}$ each, then dried. The sections were then bathed in $0.1 \mathrm{mM}$ citrate buffer ( $\mathrm{pH}$ 6) solution at $85^{\circ} \mathrm{C}$ for $30 \mathrm{~min}$ and again dehydrated in a series of ethanol solutions and dried.

The slides were incubated in $0.75 \mathrm{ml}$ of pepsin (Sigma) solution $(4 \mathrm{mg} / \mathrm{ml}$ in $0.9 \% \mathrm{NaCl}, \mathrm{pH} 1.5)$ for $15 \mathrm{~min}$ at $37^{\circ} \mathrm{C}$, washed again, dehydrated again in graded ethanol solutions (70, 85, and 100\%) for 2 min each and dried.

A total of $10 \mu \mathrm{l}$ RET (10q11) break-apart probe was placed on the designated hybridization area and sealed with rubber cement.

A ThermoBrite denaturation-hybridization system (Abbott Molecular) set at $80^{\circ} \mathrm{C}$ was used for codenaturation of probe and target DNA for $10 \mathrm{~min}$, before hybridization at $37^{\circ} \mathrm{C}$ overnight.

The rubber cement and coverslip were removed and the slides were placed in $0.3 \% \mathrm{NP}-40 / 2 \times$ SSC solution at first for $15 \mathrm{~min}$ at room temperature and then at $72{ }^{\circ} \mathrm{C}$ for $2 \mathrm{~min}$. The sections were then rinsed in $\mathrm{H}_{2} \mathrm{O}$ for $1 \mathrm{~min}$, airdried, and counterstained with $10 \mathrm{ml}$ of DAPI/Antifade

Table 2 Clinico-pathological and molecular findings in follicular adenoma.

\begin{tabular}{|c|c|c|c|c|}
\hline Samples & $\begin{array}{c}\text { Age } \\
\text { (years) }\end{array}$ & Gender & $\begin{array}{l}\text { Radiation } \\
\text { exposure }\end{array}$ & $\begin{array}{l}\text { Diameter } \\
(\mathrm{mm})\end{array}$ \\
\hline 1 & 35 & $\mathrm{M}$ & Yes & 6 \\
\hline 2 & 52 & $\mathrm{M}$ & No & 22 \\
\hline 3 & 32 & $F$ & No & 27 \\
\hline 4 & 54 & $F$ & No & 25 \\
\hline 5 & 31 & $F$ & No & 40 \\
\hline 6 & 46 & $\mathrm{~F}$ & No & 35 \\
\hline 7 & 39 & $\mathrm{~F}$ & No & 25 \\
\hline 8 & 54 & $\mathrm{~F}$ & No & 30 \\
\hline 9 & 54 & $F$ & No & 6 \\
\hline 10 & 60 & $\mathrm{M}$ & No & 40 \\
\hline 11 & 51 & $\mathrm{M}$ & No & 11 \\
\hline 12 & 56 & $\mathrm{M}$ & No & 20 \\
\hline 13 & 51 & $\mathrm{~F}$ & No & 8 \\
\hline
\end{tabular}

\begin{tabular}{ll}
$\begin{array}{l}\text { Histological } \\
\text { type }\end{array}$ & Architectural pattern \\
\cline { 1 - 1 } $\begin{array}{l}\text { Follicular } \\
\text { Follicular }\end{array}$ & $\begin{array}{l}\text { Normo-macrofollicular } \\
\text { Mollicular }\end{array}$ \\
Follicular & Microfollocular and trabecular \\
Follicular & Microfollicular \\
Oncocytic & Solid and follicular \\
Oncocytic & Microfollicular and trabecular \\
Oncocytic & Normo-macrofollicular \\
Oncocytic & Microfollicular and trabecular \\
Oncocytic & Solid-trabecular \\
Oncocytic & Normo-macrofollicular \\
Oncocytic & Solid-trabecular \\
Hyalinizing & Trabecular \\
trabecular & \\
\hline
\end{tabular}

\begin{tabular}{c}
$\begin{array}{c}\text { Split } \boldsymbol{R E T} \\
\text { signals }(\%)\end{array}$ \\
\hline 2 \\
4 \\
12 \\
3 \\
4 \\
2 \\
1 \\
6 \\
2 \\
1 \\
4 \\
4 \\
4
\end{tabular}

www.eje-online.org 
(ProLong Gold Antifade Reagent with DAPI; Life Technologies). The slides were examined using an Olympus BIX-61 microscope (Olympus, Hamburg, Germany) with appropriate fluorescence excitation/emission filters. The signals were recorded by a CCD camera (Olympus Digital Camera). For microscopic evaluation, at least 100 intact and nonoverlapping cell nuclei were scored for the presence of a split signal. Only cells with two overlapping signals or one split and one overlapping signal were counted to ensure only complete cell nuclei had been scored. The signal pattern interpretation was as follows: interphase nucleus with two co-localized green/red fusion signals identified normal chromosomes ten, while a separated red and green signals and green/red fusion signals indicated rearranged RET.

\section{FISH cut-off level}

To establish the cut-off level for RET/PTC rearrangements, we performed FISH analysis on ten normal thyroid parenchyma and 100 nuclei were scored for the presence of a split signal. As previously reported, the cut-off value was calculated as mean value +3 S.D. of $R E T$ rearranged cells $(23,37,50,55)$. The resulting mean value was $3.6 \%$ with a S.D. of $2.2 \%$, leading to a positivity threshold of $10.2 \%(3.6 \pm 3 \times 2.2)$. Therefore, a sample was considered positive if a broken signal was observed in $>10.2 \%$ of nuclei.

\section{RNA isolation and detection of RET/PTC rearrangements from frozen neoplastic thyroid tissue}

Total RNA was extracted and reverse transcribed into cDNA. RET/PTC1 and RET/PTC3 rearrangements have been investigated by qRT-PCR. In a final volume of $20 \mu \mathrm{l}$, we amplified $1 \mu \mathrm{g}$ cDNA in a mix containing $200 \mathrm{nM}$ final concentration of specific primers and $100 \mathrm{nM}$ of probes.

Primers forward and probes were as follows: RET/PTC1, F: 5'-CGCGACCTGCGCAAA-3'; RET/PTC3, F: 5'-CCCCAGGACTGGCTTACCC-3'; PTC1 probe, 5'-CAAGCGTAACCATCGAGGATCCAAA-3'; PTC3 probe, 5'-AAAGCAGACCTTGGAGAACAGTCAG-3'.

For both fragments, primer reverse was: RET/PTC, R: 5'-CAAGTTCTTCCGAGGGAATTCC-3'. To verify the presence of non-rearranged $R E T$, the following primers and probe were used: RET, F: $5^{\prime}$-TGCTTCTGCGAGCCC-3', R: $5^{\prime}$-ATCACCGTGCGGCACAG-3'; RET probe $5^{\prime}$-CATCCAGGATCCACTGTGCA-3'. Thermal cycling profile was $3 \mathrm{~min}$ at $95^{\circ} \mathrm{C}$ followed by $15 \mathrm{~s}$ at $95^{\circ} \mathrm{C}$ and $1 \mathrm{~min}$ at $60^{\circ} \mathrm{C}$ for 45 cycles. TPC1 cells with RET/PTC1 rearrangement and NIH3T3 cells with RET/PTC3 rearrangement were used to form a standard curve composed by five points (from 1000 to $0.1 \mathrm{ng}$ of cDNA with 1:10 dilution) (56).

\section{Agarose gel PCR}

The generic rearrangement for RET (RET/PTCX) was analyzed searching for the expression of tyrosine kinase (TK) and extracellular (EC) domains using the following primers: EC, F: 5'-GGCGGCCCAAGTGTGCCGAACTT-3', R: 5'-CCCAGGCCGCCACACTCCTCACA-3'; TK, F: 5'-TGGTTCTTGGAAAAACTCTAG-3', R: 5'-CTGCAGGCCCCATACAATTT- $3^{\prime}$. Only samples showing TK expression and not associated with EC were considered positive for rearrangement. Thermal cycling conditions included an initial step $\left(94^{\circ} \mathrm{C}\right.$ for $\left.10 \mathrm{~min}\right)$ followed by 35 cycles at $60{ }^{\circ} \mathrm{C}$ and a final extension $\left(72^{\circ} \mathrm{C}\right.$ for $\left.10 \mathrm{~min}\right)$. TPC1 cells (rearranged for RET/PTC1) were used as a positive control and BCPAP cells (carrying the BRAFV600E mutation) were used as a negative control (42).

\section{BRAF status}

$B R A F$ sequence was screened for V600E mutation by pyrosequencing. DNA was first amplified using 'RotorGene 6000' (Corbett Research, St. Neots, Cambridgeshire, UK) and then sequenced using PyroMark Q96 ID system. PCR was performed with the following conditions: initial denaturation at $95^{\circ} \mathrm{C}$ for $3 \mathrm{~min} ; 40$ cycles at $95^{\circ} \mathrm{C}$ for $30 \mathrm{~s}$, $55^{\circ} \mathrm{C}$ for $30 \mathrm{~s}, 72^{\circ} \mathrm{C}$ for $30 \mathrm{~s}$; final step $60^{\circ} \mathrm{C}$ for 5 min with TaKaRa Ex Taq (Qiagen). PCR amplification and mutational analysis were performed in accordance with the Diatech manual (anti-EGFR MoAb response BRAF status).

\section{Statistical analyses}

For statistical analysis, the unpaired Student's t-tests, the $\chi^{2}$, and the Fisher's exact test were used, as appropriate. Statistical significance was defined at $P<0.05$. The $P$ values were corrected for multiple testing according to Bonferroni. All analyses were performed using GraphPad Prism version 5.00 for Windows (GraphPad Software, San Diego, CA, USA; www.graphpad.com).

\section{Results}

The clinico-pathological and molecular features of the 46 PTC (40 PTC BRAF WT and six PTC with BRAFV600E mutation) and $13 \mathrm{FA}$ cases are given in Tables 1, 2 and 3. 
Table 3 Clinico-pathological features of BRAF WT PTC patients. One case of FAP-associated papillary carcinoma; one case of sporadic cribriform-morular variant of papillary carcinoma; one case of a recurrence nodule in thyroid bed.

\begin{tabular}{lc}
\hline Parameter & Number \\
\cline { 1 - 2 } Mean age (years) & $35.5(8-75)$ \\
Mean tumor size (mm) & $22.5(3-60)$ \\
Diameter $\leq 1 \mathrm{~cm}$ & $13(32.5 \%)$ \\
Multifocality & $12(33 \%)$ \\
Thyroiditis & $16(44 \%)$ \\
pT1-2 & $18(49 \%)$ \\
pT3-4 & $19(51 \%)$ \\
pN1 & $18(49 \%)$ \\
Stage (AJCC 2009) & \\
I-II & $31(84 \%)$ \\
III-IV & $6(16 \%)$ \\
\hline
\end{tabular}

The mean age of the patients with $B R A F$ WT PTC and with FA was 35.5 and 46.7 years respectively.

In the former group, there were 28 females and nine males, resulting in a female:male ratio of 3.1:1. In the latter group, there were seven females and five males with a sex ratio of $1.4: 1$.

The mean tumor size of the $B R A F$ WT PTC samples was $22.5 \mathrm{~mm}$ and $32.5 \%$ of them were microcarcinomas. Moreover, multifocality was present in 33\% of the samples, and lymph node metastases were found in about $49 \%$ of the patients. Following the TNM staging (57), 31 patients were at stage I and II (Table 3).

Assuming that BRAFV600E mutation and RET/PTC aberration are usually mutually exclusive $(58,59)$, the overall prevalence of RET rearrangement, including all 250 PTCs, was $4 \%$ whereas if we consider only the BRAF WT PTC samples, the prevalence was $25 \%$ (10/40 cases) (Fig. 1).

In detail, eight out of ten RET-positive cases showed a high percentage of split, ranging from 18 to $50 \%$, while two cases harbored 12 and 13\% of positive nuclei, respectively (Table 1 ). In the cases with low percentage of split, the aberrant cells were found scattered in the contest of cells harboring normal chromosome 10, without clustering. RET rearrangement was observed in nine sporadic PTCs (two solid, two classical, three follicular, two diffuse sclerosing variants) and in one with a history of exposure to external beam radiotherapy (classical variant; Fig. 2). Considering only the group of PTCs exposed to radiation, the frequency of RET rearrangement was $17 \%$ (one out of six cases with $30 \%$ of rearranged cells). The patient had received whole total body radiotherapy for leukemia 7 years before the diagnosis and removal of thyroid cancer (Table 1, case 32 ). Overall, the patients are young in age, the majority have lymph node metastases at the diagnosis and have PTC variants at the histology, frequently linked to RET genotype (Table 1).

All six PTC samples, carrying BRAFV600E mutation detected through pyrosequencing, showed a percentage of RET-positive cells under the cut-off threshold (range 2-8\%) (Table 1). Both molecular aberrations were mutually exclusive.

The comparison between FISH and qRT-PCR results are depicted in Table 1.
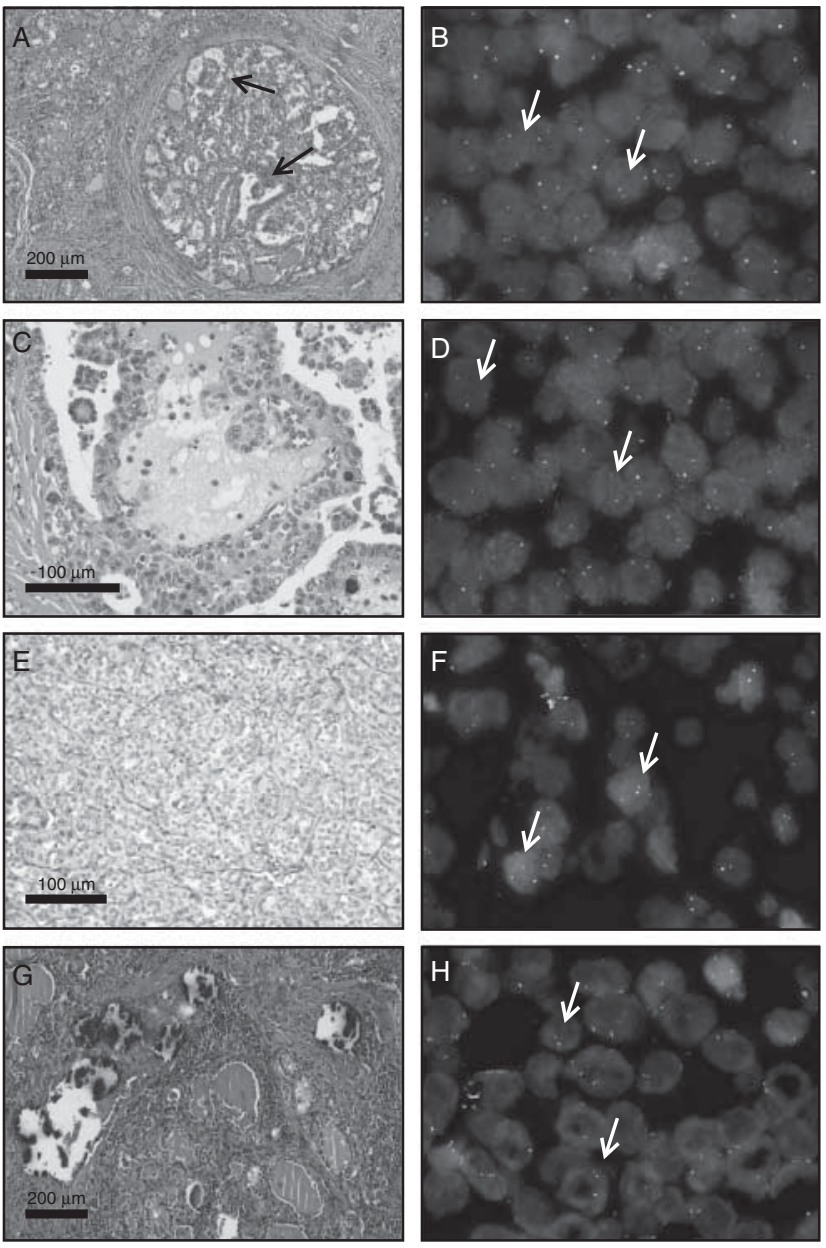

\section{Figure 2}

Histology and corresponding FISH images of representative RET rearranged PTC samples. (A and B) Classical variant PTC with predominant follicular growth pattern (case 29, Table 1). Black arrows indicate papillary structures. (C and D) Classical variant PTC with a history of exposure to external beam radiotherapy (case 35, Table 1). (E and F) Solid variant PTC (case 27, Table 1). (G and H) Diffuse sclerosing variant PTC (case 33, Table 1). White arrows indicate the rearranged copy of RET. A full colour version of this figure is available at http://dx.doi.org/10.1530/ EJE-14-0930. 
All ten RET positive PTC cases analyzed by FISH matched well with qRT-PCR data. In particular, nine out of ten cases (n. 20b, 24, 26, 27, 28, 29, 30, 31, and 32) showed detectable RET/PTC1 mRNA, while one case (n. 25) exhibited RET/PTC3 mRNA.

Controversial data were obtained in five cases showing a frequency of rearrangement very close to the cut-off level. Cases 6, 12, and 16, displaying 6, 9, and $10 \%$ of aberrant nuclei, respectively, showed detectable RET/PTC3 or RET/PTC1 mRNA, while samples n.15 and n.19 exhibited no detectable RET/PTC1, RET/PTC3, and tyrosine kinase domain mRNA expression and 10\% of split FISH signals.

Moreover, the remaining $25 B R A F$ WT PTC cases and all six BRAFV600E cases were negative by both methods.

Finally, we found RET/PTC activation in one spontaneous FA (one out of 13 cases, 7.7\%), harboring split signals in $12 \%$ of the nuclei, above the cut-off threshold (Table 2).

The comparison between RET rearranged and non rearranged PTCs is summarized in Table 4. No significant differences were found concerning the clinico-pathological features, with the exception of the frequency of extrathyroidal invasion which was significantly higher in tumors with RET rearrangement than those harboring $R E T$ WT $(P=0.027$; Table 4$)$.

\section{Discussion}

RET/PTC was the first chimeric gene with oncogenic potential described in a tumor of epithelial origin and represents one of the major genetic alterations found in PTC $(1,60)$.

Table 4 Comparison between the clinico-pathological data of rearranged and non-rearranged RETIPTC samples.

\begin{tabular}{|c|c|c|c|}
\hline & $\begin{array}{c}\text { Rearranged } \\
\text { RET }\end{array}$ & $\begin{array}{c}\text { Non- } \\
\text { rearranged } \\
\text { RET }\end{array}$ & $P$ value \\
\hline Gender (M:F) & $1: 4$ & $1: 2.9$ & NS \\
\hline Mean age (years \pm S.E.M.) & $31( \pm 4.1)$ & $37.1( \pm 3.2)$ & NS \\
\hline Tumor diameter (mm \pm s.E.M.) & $25.6( \pm 4.3)$ & $17( \pm 3.1)$ & NS \\
\hline Multicentricity & $2(20 \%)$ & $10(37 \%)$ & NS \\
\hline рT3 & $9(90 \%)$ & $9(33.3 \%)$ & 0.027 \\
\hline Thyroiditis & $6(60 \%)$ & $10(37 \%)$ & NS \\
\hline Lymph node involvement & $7(70 \%)$ & $11(40.7 \%)$ & NS \\
\hline Stage (AJCC 2009) & & & NS \\
\hline I-II & $9(90 \%)$ & $22(81.5 \%)$ & \\
\hline III-IV & $1(10 \%)$ & $5(18.5 \%)$ & \\
\hline Histological subtype & & & NS \\
\hline Follicular & $3(30 \%)$ & $15(50 \%)$ & \\
\hline Classical & $3(30 \%)$ & $8(26.7 \%)$ & \\
\hline Tall cell & $0(0 \%)$ & $1(3.3 \%)$ & \\
\hline Others & $4(40 \%)$ & $6(20 \%)$ & \\
\hline
\end{tabular}

For almost two decades, the pathogenic role of this hybrid gene both in sporadic PTC (adult and pediatric) and in PTC developing after ionizing radiation exposure, has been considered a dogma, but the detection of RETpositive cells in benign thyroid lesions and the discovery of heterogeneous distribution of this rearrangement within an individual nodule have called into question the belief $(22,24,25,37,61)$.

Moreover, the clinical significance of RET/PTC rearrangements is still debated. Indeed, some authors have suggested that RET rearrangements are associated with local invasion and distant metastases $(17,26,62,63$, $64,65)$ while other authors associated with early-stage small PTCs and better prognosis $(30,66,67,68,69,70)$. However, these studies assumed that all types of rearrangement have comparable properties and considered them as a group (19).

Thus, the current challenge in using RET/PTC analysis affects the interpretation of dataset results. Finding an accurate, reliable, and clinically pragmatic strategy for $R E T / P T C$ detection becomes imperative because the detection of RET/PTC has been offered as a diagnostic tool for PTC in the surgical and preoperative cytological material $(3,21,40,41,42,43,44)$. FISH is considered as the assay of choice for rearrangement detection on formalinfixed surgical samples (71) and according to Marotta et al. (21), at present, it is the most suitable method for detecting clonal changes. Moreover, the application of interphase FISH on thyroid tumors is appropriate as tumors of endocrine glands are known to have a low growth rate (72).

The aim of this study was to investigate the prevalence of RET rearrangement by interphase FISH analysis in a cohort of BRAF WT PTC and to search for a reliable cut-off value in order to distinguish the occurrence of clonal or non-clonal RET changes and to explore whether RET/PTC may be a relevant pathogenic factor.

In our series, we found a total of ten out of 40 (25\%) $B R A F$ WT PTC samples with broken RET above the cut-off level, a prevalence slightly lower than that reported in other Italian studies of comparable size, ranging from 27.5 to $35 \%(16,30,62,73,74)$.

This finding could be explained by the significant decrease in $R E T / P T C$ over the years and the equivalent increasing rate of $B R A F V 600 \mathrm{E}$ and $R A S$ mutations in PTC, possibly attributed to the decreased exposure to ionizing radiation in the last decades or to new pollutants $(75,76$, 77, 78, 79).

Moreover, the prevalence of $4 \%$ of $R E T$-positive samples in our consecutive series of 250 PTCs is consistent 
with Jung et al. (76) who documented the decreasing in RET/PTC rearrangement from 11 to $2 \%$. This prevalence was calculated assuming that RET rearrangement and $B R A F$ V600E mutation are mutually exclusive as reported in some studies which consider the two genetic alterations as separated events in PTC without overlap $(58,59)$. Moreover, de Biase et al. (80) demonstrated that $B R A F \mathrm{~V} 600 \mathrm{E}$ is present in virtually all/the majority neoplastic cells in many mutated PTCs supporting the idea of that this genetic alteration is a founding event, acquired early during PTC development.

All six BRAFV600E samples tested for RET rearrangements exhibited split signal under the cut-off level. This finding indirectly confirms the pertinence of the $10.2 \%$ threshold for distinguishing non-clonal from subclonal or clonal $R E T / P T C$ rearrangement given that $B R A F$ V600E mutation and RET/PTC aberration are usually mutually exclusive $(58,59)$. Moreover, this cut-off level parallels previous studies, which used a cut-off level of between 5 and $10 \%$ to separate cases from false-positives $(22,81,82,83)$.

We detected RET/PTC rearrangement in one of the six patients $(17 \%)$ with a history of exposure to external beam radiotherapy. In the context of thyroid irradiation, this finding is to be considered a low figure, although the values reported in the literature have been decreasing recently $(71,75,84)$. The high variation of $R E T / P T C$ rearrangements reported in different series can be due to differences in the prevalence of this alteration in specific age groups or due to the different time of latency of the tumors $(3,71,84,85)$.

In order to validate FISH results, we performed qRT-PCR assay in our study cohort composed of $40 B R A F$ WT and six BRAFV600E PTC cases. The FISH results matched well with qRT-PCR in 41 PTC cases (31 BRAF WT and six BRAFV600E PTCs), whereas five cases (n. 6, 12, 15,16 , and 19), showing a frequency of rearrangement very close to the cut-off level, were discordant (Table 1).

This discrepancy may reflect the genetic heterogeneity within an individual tumor, the different sensitivity of the detection approaches used in the study and the samples type used for the comparative analysis, e.g. FFPE material for FISH analysis and frozen tissue for qRT-PCR, representing different regions of the same tumor presumably with different distribution of $R E T$-positive cells $(3,22)$. Moreover, the documented highly variable levels of RET/PTC expression in PTC, the identification of which is strictly dependent on factors that affect the sensitivity, could contribute to explaining the inconsistencies in detection rates between the DNA-based method (FISH) and RNA- based assay (qRT-PCR). The existence of quantitative variation in the expression levels should be taken into account to investigate the correlation of RET/PTC with clinical findings $(83,86)$.

The clinical significance of $R E T / P T C$ remains unclear, with conflicting results between the studies. Considering the clinico-pathological features evaluated in our series, we found no correlation of RET/PTC expression with age, gender, tumor size, histological variant, multifocality, lymphocytic infiltration, and lymph node metastasis, but the frequency of extrathyroidal invasion in tumors with RET/PTC expression $(9 / 10,90 \%)$ was significantly higher than those of RET/PTC negative $(9 / 27,33 \%, P=0.027)$, as already reported in three other studies $(87,88,89)$. However, follow-up analysis seems to indicate no influence of RET expression on patients' outcome, although the short follow-up period makes it difficult to draw definitive and firm conclusions on the prognosis. According to Tallini et al. (68), only one case of PTC with minor poorly differentiated component (case 23) was negative for RET rearrangement, confirming the low potential (the apparent inability) of RET/PTC-positive PTC to progress to a less differentiated phenotype.

As in the study of Soares et al. (69), our series did not include papillary microcarcinoma, carrying RET rearrangement. However, a high prevalence of RET rearrangement has been detected in papillary microcarcinomas by Viglietto et al. (67), leading the authors to conclude that this genetic alteration is an early event in PTC tumorigenesis and occurs in tumors with less propensity to evolve toward clinically more aggressive forms. Also Corvi et al. (90) found RET activation in 11 microcarcinomas out of 21 (52\%) using FISH method. It is likely that these discrepancies could be attributed to the different study populations evaluated.

We found RET/PTC activation in one spontaneous FA (one out of 13 cases, $7.7 \%$ ), harboring split signals in $12 \%$ of the nuclei. Although, initially, RET rearrangements were considered as a specific marker for PTC, they have been sporadically reported in nodules classified as benign at histology by means of different detection methods (21, 29, 32, 46). The biological significance of RET/PTC in benign lesions remains difficult to explain, if we exclude the occurrence of microfoci of PTC within an otherwise benign nodule. Some authors have hypothesized that the RET-positive adenomas are composed of a mixture of cells with and without rearrangement (nonclonal event), while others suggested that adenomas RET/PTC-positive may grow faster than those RET/PTCnegative $(23,32,36,46)$. 
In conclusion, this study demonstrates that interphase break-apart FISH analysis proves a reliable and sensitive strategy to detect RET/PTC activation in thyroid tumors, comparable with RT-PCR or Southern blot analysis with the advantage to allow, on histology sections, the direct correlation between the histopathological features and the distribution of RET rearrangements in the tumor/nontumor cells. It also represents a powerful tool to estimate the ratio between broken and non-broken $R E T$ cells in an individual tumor, with the possibility to separate the clonal (driver mutation) from subclonal event (passenger mutation) and to quantifying intratumoral genetic heterogeneity.

Finally, the identification of a precise laboratory FISH cut-off appears to be a pivotal prerequisite in the interpretation of the presence of RET rearrangement, particularly when $R E T / P T C$ detection is used for cytological evaluation of malignancy or for targeted therapy.

\section{Declaration of interest}

The authors declare that there is no conflict of interest that could be perceived as prejudicing the impartiality of the research reported.

\section{Funding}

C Vicentini is supported by the ARC-NET Research Centre at Verona University.

\section{Author contribution statement}

All authors approved the final version of the manuscript. Study concept and design: C Colato, M Ferdeghini, M Chilosi, F Pacini, and M Brunelli. Acquisition of data: C Colato, C Vicentini, S Cantara, S Pedron, P Brazzarola, I Marchetti, and G D Coscio. Analysis and interpretation of data: C Colato, C Vicentini, S Cantara, F Pacini, M Chilosi, M Ferdeghini, and M Brunelli. Drafting of the manuscript: $\mathrm{C}$ Vicentini and $\mathrm{C}$ Colato.

\section{References}

1 Fusco A, Grieco M, Santoro M, Berlingieri MT, Pilotti S, Pierotti MA, Della Porta G \& Vecchio G. A new oncogene in human thyroid papillary carcinomas and their lymph-nodal metastases. Nature $1987 \mathbf{3 2 8}$ 170-172. (doi:10.1038/328170a0)

2 Grieco M, Santoro M, Berlingieri MT, Melillo RM, Donghi R, Bongarzone I, Pierotti MA, Della Porta G, Fusco A \& Vecchio G. PTC is a novel rearranged form of the ret proto-oncogene and is frequently detected in vivo in human thyroid papillary carcinomas. Cell 199060 557-563. (doi:10.1016/0092-8674(90)90659-3)

3 Nikiforov YE \& Nikiforova MN. Molecular genetics and diagnosis of thyroid cancer. Nature Reviews. Endocrinology 20117 569-580. (doi:10.1038/nrendo.2011.142)

4 Takahashi M, Ritz J \& Cooper GM. Activation of a novel human transforming gene, ret, by DNA rearrangement. Cell 198542 581-588. (doi:10.1016/0092-8674(85)90115-1)
5 Takahashi M, Buma Y, Iwamoto T, Inaguma Y, Ikeda H \& Hiai H. Cloning and expression of the ret proto-oncogene encoding a tyrosine kinase with two potential transmembrane domains. Oncogene 19883 571-578.

6 Tallini G \& Asa SL. RET oncogene activation in papillary thyroid carcinoma. Advances in Anatomic Pathology 2001 8 345-354. (doi:10.1097/00125480-200111000-00005)

7 Nikiforov YE. RET/PTC rearrangement in thyroid tumors. Endocrine Pathology 200213 3-16. (doi:10.1385/EP:13:1:03)

8 Ricarte-Filho JC, Ryder M, Chitale DA, Rivera M, Heguy A, Ladanyi M, Janakiraman M, Solit D, Knauf JA, Tuttle RM et al. Mutational profile of advanced primary and metastatic radioactive iodine-refractory thyroid cancers reveals distinct pathogenetic roles for BRAF, PIK3CA, and AKT1. Cancer Research 200969 4885-4893. (doi:10.1158/0008-5472.CAN09-0727)

9 Santoro M, Sabino N, Ishizaka Y, Ushijima T, Carlomagno F, Cerrato A, Grieco M, Battaglia C, Martelli ML, Paulin C et al. Involvement of RET oncogene in human tumours: specificity of RET activation to thyroid tumours. British Journal of Cancer 199368 460-464. (doi:10.1038/bjc. 1993.370)

10 Jhiang SM, Cho JY, Furminger TL, Sagartz JE, Tong Q, Capen CC \& Mazzaferri EL. Thyroid carcinomas in RET/PTC transgenic mice. Recent Results in Cancer Research 1998154 265-270.

11 Powell DJ Jr, Russell J, Nibu K, Li G, Rhee E, Liao M, Goldstein M, Keane WM, Santoro M, Fusco A et al. The RET/PTC3 oncogene: metastatic solid-type papillary carcinomas in murine thyroids. Cancer Research $1998 \mathbf{5 8} 5523-5528$.

12 Santoro M, Chiappetta G, Cerrato A, Salvatore D, Zhang L, Manzo G, Picone A, Portella G, Santelli G, Vecchio G et al. Development of thyroid papillary carcinomas secondary to tissue-specific expression of the RET/PTC1 oncogene in transgenic mice. Oncogene 199612 1821-1826.

13 Castellone MD \& Santoro M. Dysregulated RET signaling in thyroid cancer. Endocrinology and Metabolism Clinics of North America 200837 363-374, viii. (doi:10.1016/j.ecl.2008.02.006)

14 Santoro M, Dathan NA, Berlingieri MT, Bongarzone I, Paulin C, Grieco M, Pierotti MA, Vecchio G \& Fusco A. Molecular characterization of RET/PTC3; a novel rearranged version of the RETprotooncogene in a human thyroid papillary carcinoma. Oncogene 19949 509-516.

15 Zou M, Shi Y \& Farid NR. Low rate of ret proto-oncogene activation (PTC/retTPC) in papillary thyroid carcinomas from Saudi Arabia. Cancer 199473 176-180. (doi:10.1002/1097-0142(19940101)73:1<176:: AID-CNCR2820730130>3.0.CO;2-T)

16 Santoro M, Carlomagno F, Hay ID, Herrmann MA, Grieco M, Melillo R, Pierotti MA, Bongarzone I, Della Porta G, Berger N et al. Ret oncogene activation in human thyroid neoplasms is restricted to the papillary cancer subtype. Journal of Clinical Investigation 199289 1517-1522. (doi:10.1172/JCI115743)

17 Sugg SL, Ezzat S, Zheng L, Freeman JL, Rosen IB \& Asa SL. Oncogene profile of papillary thyroid carcinoma. Surgery 1999125 46-52. (doi:10.1016/S0039-6060(99)70287-4)

18 Learoyd DL, Messina M, Zedenius J, Guinea AI, Delbridge LW \& Robinson BG. RET/PTC and RET tyrosine kinase expression in adult papillary thyroid carcinomas. Journal of Clinical Endocrinology and Metabolism 199883 3631-3635. (doi:10.1210/jcem.83.10.5152)

19 Nikiforov YE. Recent developments in the molecular biology of the thyroid. Edn 2, ch 10, pp 237-260. Ed Ricardo V. Lloyd. Berlin: Springer, 2010.

20 Sugg SL, Ezzat S, Rosen IB, Freeman JL \& Asa SL. Distinct multiple RET/PTC gene rearrangements in multifocal papillary thyroid neoplasia. Journal of Clinical Endocrinology and Metabolism $1998 \mathbf{8 3}$ 4116-4122. (doi:10.1210/jcem.83.11.5271)

21 Marotta V, Guerra A, Sapio MR \& Vitale M. RET/PTC rearrangement in benign and malignant thyroid diseases: a clinical standpoint. European Journal of Endocrinology 2011165 499-507. (doi:10.1530/EJE-11-0499) 
22 Unger K, Zitzelsberger H, Salvatore G, Santoro M, Bogdanova T, Braselmann H, Kastner P, Zurnadzhy L, Tronko N, Hutzler P et al. Heterogeneity in the distribution of RET/PTC rearrangements within individual post-Chernobyl papillary thyroid carcinomas. Journal of Clinical Endocrinology and Metabolism 200489 4272-4279. (doi:10.1210/ jc.2003-031870)

23 Zhu Z, Ciampi R, Nikiforova MN, Gandhi M \& Nikiforov YE. Prevalence of RET/PTC rearrangements in thyroid papillary carcinomas: effects of the detection methods and genetic heterogeneity. Journal of Clinical Endocrinology and Metabolism 200691 3603-3610. (doi:10.1210/jc. 2006-1006)

24 Guerra A, Sapio MR, Marotta V, Campanile E, Moretti MI, Deandrea M, Motta M, Limone PP, Fenzi G, Rossi G et al. Prevalence of RET/PTC rearrangement in benign and malignant thyroid nodules and its clinical application. Endocrine Journal 201158 31-38. (doi:10.1507/ endocrj.K10E-260)

25 Nikiforov YE, Rowland JM, Bove KE, Monforte-Munoz H \& Fagin JA. Distinct pattern of ret oncogene rearrangements in morphological variants of radiation-induced and sporadic thyroid papillary carcinomas in children. Cancer Research 199757 1690-1694.

26 Rabes HM, Demidchik EP, Sidorow JD, Lengfelder E, Beimfohr C, Hoelzel D \& Klugbauer S. Pattern of radiation-induced RET and NTRK1 rearrangements in 191 post-Chernobyl papillary thyroid carcinomas: biological, phenotypic, and clinical implications. Clinical Cancer Research 20006 1093-1103.

27 Bongarzone I, Fugazzola L, Vigneri P, Mariani L, Mondellini P, Pacini F, Basolo F, Pinchera A, Pilotti S \& Pierotti MA. Age-related activation of the tyrosine kinase receptor protooncogenes RET and NTRK1 in papillary thyroid carcinoma. Journal of Clinical Endocrinology and Metabolism 199681 2006-2009. (doi:10.1210/jcem.81.5.8626874)

28 Fenton CL, Lukes Y, Nicholson D, Dinauer CA, Francis GL \& Tuttle RM. The ret/PTC mutations are common in sporadic papillary thyroid carcinoma of children and young adults. Journal of Clinical Endocrinology and Metabolism 200085 1170-1175. (doi:10.1210/jcem.85.3. 6472)

29 Bounacer A, Wicker R, Caillou B, Cailleux AF, Sarasin A, Schlumberger M \& Suarez HG. High prevalence of activating ret proto-oncogene rearrangements, in thyroid tumors from patients who had received external radiation. Oncogene 199715 1263-1273. (doi:10.1038/sj.onc.1200206)

30 Elisei R, Romei C, Vorontsova T, Cosci B, Veremeychik V, Kuchinskaya E, Basolo F, Demidchik EP, Miccoli P, Pinchera A et al. RET/PTC rearrangements in thyroid nodules: studies in irradiated and not irradiated, malignant and benign thyroid lesions in children and adults. Journal of Clinical Endocrinology and Metabolism 200186 3211-3216. (doi:10.1210/jcem.86.7.7678)

31 Sassolas G, Hafdi-Nejjari Z, Ferraro A, Decaussin-Petrucci M, Rousset B, Borson-Chazot F, Borbone E, Berger N \& Fusco A. Oncogenic alterations in papillary thyroid cancers of young patients. Thyroid 201222 17-26. (doi:10.1089/thy.2011.0215)

32 Ishizaka Y, Kobayashi S, Ushijima T, Hirohashi S, Sugimura T \& Nagao M. Detection of retTPC/PTC transcripts in thyroid adenomas and adenomatous goiter by an RT-PCR method. Oncogene 19916 $1667-1672$

33 Wirtschafter A, Schmidt R, Rosen D, Kundu N, Santoro M, Fusco A, Multhaupt H, Atkins JP, Rosen MR, Keane WM et al. Expression of the RET/PTC fusion gene as a marker for papillary carcinoma in Hashimoto's thyroiditis. Laryngoscope 1997 107 95-100. (doi:10.1097/ 00005537-199701000-00019)

34 Sheils OM, O'Eary JJ, Uhlmann V, Lattich K \& Sweeney EC. ret/PTC-1 activation in Hashimoto's thyroiditis. International Journal of Surgical Pathology 20008 185-189. (doi:10.1177/106689690000800305)

35 Chiappetta G, Toti P, Cetta F, Giuliano A, Pentimalli F, Amendola I, Lazzi S, Monaco M, Mazzuchelli L, Tosi P et al. The RET/PTC, oncogene is frequently activated in oncocytic thyroid tumors (Hurthle cell adenomas and carcinomas), but not in oncocytic hyperplastic lesions.
Journal of Clinical Endocrinology and Metabolism 200287 364-369. (doi:10.1210/jcem.87.1.8180)

36 Sapio MR, Guerra A, Marotta V, Campanile E, Formisano R, Deandrea M, Motta M, Limone PP, Fenzi G, Rossi G et al. High growth rate of benign thyroid nodules bearing RET/PTC rearrangements. Journal of Clinical Endocrinology and Metabolism 201196 E916-E919. (doi:10.1210/jc.2010-1599)

37 Rhoden KJ, Unger K, Salvatore G, Yilmaz Y, Vovk V, Chiappetta G, Qumsiyeh MB, Rothstein JL, Fusco A, Santoro M et al. RET/papillary thyroid cancer rearrangement in nonneoplastic thyrocytes: follicular cells of Hashimoto's thyroiditis share low-level recombination events with a subset of papillary carcinoma. Journal of Clinical Endocrinology and Metabolism 200691 2414-2423. (doi:10.1210/jc. 2006-0240)

38 Cetta F, Gori M, Montalto G, Zuckermann M \& Toti P. Different significance of ret/PTC(1) and ret/PTC(3) rearrangements in thyroid carcinogenesis: lesson from two subgroups of patients with papillary thyroid carcinomas showing the highest incidence of ret/PTC activation. Journal of Clinical Endocrinology and Metabolism 2001 86 1429. (doi:10.1210/jcem.86.3.7352-8)

39 Papotti M, Volante M, Giuliano A, Fassina A, Fusco A, Bussolati G, Santoro M \& Chiappetta G. RET/PTC activation in hyalinizing trabecular tumors of the thyroid. American Journal of Surgical Pathology 200024 1615-1621. (doi:10.1097/00000478-200012000-00004)

40 Cheung CC, Carydis B, Ezzat S, Bedard YC \& Asa SL. Analysis of ret/PTC gene rearrangements refines the fine needle aspiration diagnosis of thyroid cancer. Journal of Clinical Endocrinology and Metabolism 200186 2187-2190. (doi:10.1210/jcem.86.5.7504)

41 Salvatore G, Giannini R, Faviana P, Caleo A, Migliaccio I, Fagin JA, Nikiforov YE, Troncone G, Palombini L, Basolo F et al. Analysis of BRAF point mutation and RET/PTC rearrangement refines the fine-needle aspiration diagnosis of papillary thyroid carcinoma. Journal of Clinical Endocrinology and Metabolism 200489 5175-5180. (doi:10.1210/ jc.2003-032221)

42 Cantara S, Capezzone M, Marchisotta S, Capuano S, Busonero G, Toti P, Di Santo A, Caruso G, Carli AF, Brilli L et al. Impact of proto-oncogene mutation detection in cytological specimens from thyroid nodules improves the diagnostic accuracy of cytology. Journal of Clinical Endocrinology and Metabolism 201095 1365-1369. (doi:10.1210/ jc.2009-2103)

43 Ferraz C, Rehfeld C, Krogdahl A, Precht Jensen EM, Bosenberg E, Narz F, Hegedus L, Paschke R \& Eszlinger M. Detection of PAX8/PPARG and RET/PTC rearrangements is feasible in routine air-dried fine needle aspiration smears. Thyroid 201222 1025-1030. (doi:10.1089/ thy.2011.0391)

44 Caria P, Dettori T, Frau DV, Borghero A, Cappai A, Riola A, Lai ML, Boi F, Calo P, Nicolosi A et al. Assessing RET/PTC, in thyroid nodule fineneedle aspirates: the FISH point of view. Endocrine-Related Cancer 2013 20 527-536. (doi:10.1530/ERC-13-0157)

45 Witt RL, Ferris RL, Pribitkin EA, Sherman SI, Steward DL \& Nikiforov YE. Diagnosis and management of differentiated thyroid cancer using molecular biology. Laryngoscope 2013123 1059-1064. (doi:10.1002/ lary.23838)

46 Cinti R, Yin L, Ilc K, Berger N, Basolo F, Cuccato S, Giannini R, Torre G, Miccoli P, Amati P et al. RET rearrangements in papillary thyroid carcinomas and adenomas detected by interphase FISH. Cytogenetics and Cell Genetics 200088 56-61. (doi:10.1159/000015485)

47 Carlomagno F, Vitagliano D, Guida T, Ciardiello F, Tortora G, Vecchio G, Ryan AJ, Fontanini G, Fusco A \& Santoro M. ZD6474, an orally available inhibitor of KDR tyrosine kinase activity, efficiently blocks oncogenic RET kinases. Cancer Research 200262 7284-7290.

48 Lanzi C, Cassinelli G, Nicolini V \& Zunino F. Targeting RET, for thyroid cancer therapy. Biochemical Pharmacology 200977 297-309. (doi:10.1016/j.bcp.2008.10.033) 
49 Puxeddu E, Romagnoli S \& Dottorini ME. Targeted therapies for advanced thyroid cancer. Current Opinion in Oncology 201123 13-21. (doi:10.1097/CCO.0b013e328340cf94)

50 Nakazawa T, Murata S, Kondo T, Niu D, Mochizuki K, Kawasaki T, Yamane T, Nakamura N \& Katoh R. RET/PTC rearrangements arising from a small population of papillary thyroid carcinoma cells, possible candidate for passenger mutation. Virchows Archiv 2009455 35-41. (doi:10.1007/s00428-009-0789-8)

51 Drieschner N, Rippe V, Laabs A, Dittberner L, Nimzyk R, Junker K, Rommel B, Kiefer Y, Belge G, Bullerdiek J et al. Interphase fluorescence in situ hybridization analysis detects a much higher rate of thyroid tumors with clonal cytogenetic deviations of the main cytogenetic subgroups than conventional cytogenetics. Cancer Genetics 2011204 366-374. (doi:10.1016/j.cancergen.2011.03.008)

52 Hieber L, Huber R, Bauer V, Schaffner Q, Braselmann H, Thomas G, Bogdanova $\mathrm{T} \&$ Zitzelsberger H. Chromosomal rearrangements in postChernobyl papillary thyroid carcinomas: evaluation by spectral karyotyping and automated interphase FISH. Journal of Biomedicine \& Biotechnology 20112011 693691. (doi:10.1155/2011/693691)

53 DeLellis RA. Pathology and Genetics of Tumours of Endocrine Organs. Edn 3, vol 8. Eds Ronald A. DeLellis, Ricardo V. Lloyd, Philipp U. Heitz \& Charis Eng. Lyon: IARC Press, 2004.

54 Calio A, Nottegar A, Gilioli E, Bria E, Pilotto S, Peretti U, Kinspergher S, Simionato F, Pedron S, Knuutila S et al. ALK/EML4 fusion gene may be found in pure squamous carcinoma of the lung. Journal of Thoracic Oncology 20149 729-732. (doi:10.1097/JTO.0000000000000109)

55 Unger K, Zurnadzhy L, Walch A, Mall M, Bogdanova T, Braselmann H, Hieber L, Tronko N, Hutzler P, Jeremiah S et al. RET rearrangements in post-Chernobyl papillary thyroid carcinomas with a short latency analysed by interphase FISH. British Journal of Cancer 200694 1472-1477. (doi:10.1038/sj.bjc.6603109)

56 Nikiforov YE, Steward DL, Robinson-Smith TM, Haugen BR, Klopper JP, Zhu Z, Fagin JA, Falciglia M, Weber K \& Nikiforova MN. Molecular testing for mutations in improving the fine-needle aspiration diagnosis of thyroid nodules. Journal of Clinical Endocrinology and Metabolism 2009 94 2092-2098. (doi:10.1210/jc.2009-0247)

57 Sobin LH, Gospodarowicz MK, Wittekind C \& Cancer IUa. TNM Classification of Malignant Tumours. Edn 7. New York: John Wiley \& Sons, 2009.

58 Kimura ET, Nikiforova MN, Zhu Z, Knauf JA, Nikiforov YE \& Fagin JA. High prevalence of BRAF mutations in thyroid cancer: genetic evidence for constitutive activation of the RET/PTC-RAS-BRAF signaling pathway in papillary thyroid carcinoma. Cancer Research 200363 1454-1457.

59 Soares P, Trovisco V, Rocha AS, Lima J, Castro P, Preto A, Maximo V, Botelho T, Seruca R \& Sobrinho-Simoes M. BRAF mutations and RET/PTC rearrangements are alternative events in the etiopathogenesis of PTC. Oncogene 200322 4578-4580. (doi:10.1038/sj.onc.1206706)

60 Grieco M, Cerrato A, Santoro M, Fusco A, Melillo RM \& Vecchio G. Cloning and characterization of H4 (D10S170), a gene involved in RET rearrangements in vivo. Oncogene 19949 2531-2535.

61 Nikiforova MN, Caudill CM, Biddinger P \& Nikiforov YE. Prevalence of RET/PTC rearrangements in Hashimoto's thyroiditis and papillary thyroid carcinomas. International Journal of Surgical Pathology 200210 15-22. (doi:10.1177/106689690201000104)

62 Bongarzone I, Vigneri P, Mariani L, Collini P, Pilotti S \& Pierotti MA. RET/NTRK1 rearrangements in thyroid gland tumors of the papillary carcinoma family: correlation with clinico-pathological features. Clinical Cancer Research $19984223-228$.

63 Jhiang SM, Caruso DR, Gilmore E, Ishizaka Y, Tahira T, Nagao M, Chiu IM \& Mazzaferri EL. Detection of the PTC/retTPC oncogene in human thyroid cancers. Oncogene 19927 1331-1337.

64 Jhiang SM \& Mazzaferri EL. The ret/PTC oncogene in papillary thyroid carcinoma. Journal of Laboratory and Clinical Medicine 1994123 331-337.
65 Thomas GA, Bunnell H, Cook HA, Williams ED, Nerovnya A, Cherstvoy ED, Tronko ND, Bogdanova TI, Chiappetta G, Viglietto G et al. High prevalence of RET/PTC rearrangements in Ukrainian and Belarussian post-Chernobyl thyroid papillary carcinomas: a strong correlation between RET/PTC3 and the solid-follicular variant. Journal of Clinical Endocrinology and Metabolism 199984 4232-4238. (doi:10.1210/jcem.84.11.6129)

66 Basolo F, Molinaro E, Agate L, Pinchera A, Pollina L, Chiappetta G, Monaco C, Santoro M, Fusco A, Miccoli P et al. RET protein expression has no prognostic impact on the long-term outcome of papillary thyroid carcinoma. European Journal of Endocrinology 2001145 599-604. (doi:10.1530/eje.0.1450599)

67 Viglietto G, Chiappetta G, Martinez-Tello FJ, Fukunaga FH, Tallini G, Rigopoulou D, Visconti R, Mastro A, Santoro M \& Fusco A. RET/PTC oncogene activation is an early event in thyroid carcinogenesis. Oncogene 199511 1207-1210.

68 Tallini G, Santoro M, Helie M, Carlomagno F, Salvatore G, Chiappetta G, Carcangiu ML \& Fusco A. RET/PTC oncogene activation defines a subset of papillary thyroid carcinomas lacking evidence of progression to poorly differentiated or undifferentiated tumor phenotypes. Clinical Cancer Research 19984 287-294.

69 Soares P, Fonseca E, Wynford-Thomas D \& Sobrinho-Simoes M. Sporadic ret-rearranged papillary carcinoma of the thyroid: a subset of slow growing, less aggressive thyroid neoplasms? Journal of Pathology 1998185 71-78. (doi:10.1002/(SICI)1096-9896(199805)185:1<71:: AID-PATH42>3.0.CO;2-S)

70 Romei C, Ciampi R, Faviana P, Agate L, Molinaro E, Bottici V, Basolo F, Miccoli P, Pacini F, Pinchera A et al. BRAFV600E mutation, but not RET/PTC rearrangements, is correlated with a lower expression of both thyroperoxidase and sodium iodide symporter genes in papillary thyroid cancer. Endocrine-Related Cancer 200815 511-520. (doi:10.1677/ERC-07-0130)

71 Boaventura P, Pereira D, Celestino R, Mendes A, Nakasawa T, Teixeira-Gomes J, Sobrinho-Simoes M \& Soares P. Genetic alterations in thyroid tumors from patients irradiated in childhood for tinea capitis treatment. European Journal of Endocrinology 2013169 673-679. (doi:10.1530/EJE-13-0543)

72 Kontogeorgos $\mathrm{G}$. The art and applications of fluorescence in situ hybridization in endocrine pathology. Endocrine Pathology 200011 123-136. (doi:10.1385/EP:11:2:123)

73 Puxeddu E, Moretti S, Giannico A, Martinelli M, Marino C, Avenia N, Cristofani R, Farabi R, Reboldi G, Ribacchi R et al. Ret/PTC activation does not influence clinical and pathological features of adult papillary thyroid carcinomas. European Journal of Endocrinology 2003148 505-513. (doi:10.1530/eje.0.1480505)

74 Santoro M, Grieco M, Melillo RM, Fusco A \& Vecchio G. Molecular defects in thyroid carcinomas: role of the RET oncogene in thyroid neoplastic transformation. European Journal of Endocrinology 1995133 513-522. (doi:10.1530/eje.0.1330513)

75 Elisei R. Molecular profiles of papillary thyroid tumors have been changing in the last decades: how could we explain it? Journal of Clinical Endocrinology and Metabolism 201499 412-414. (doi:10.1210/jc.20141130)

76 Jung CK, Little MP, Lubin JH, Brenner AV, Wells SA Jr, Sigurdson AJ \& Nikiforov YE. The increase in thyroid cancer incidence during the last four decades is accompanied by a high frequency of BRAF mutations and a sharp increase in RAS mutations. Journal of Clinical Endocrinology and Metabolism 201499 E276-E285. (doi:10.1210/jc.2013-2503)

77 Gandhi M, Dillon LW, Pramanik S, Nikiforov YE \& Wang YH. DNA breaks at fragile sites generate oncogenic RET/PTC rearrangements in human thyroid cells. Oncogene 201029 2272-2280. (doi:10.1038/onc. 2009.502)

78 Ameziane-El-Hassani R, Boufraqech M, Lagente-Chevallier O, Weyemi U, Talbot M, Metivier D, Courtin F, Bidart JM, El Mzibri M, Schlumberger $\mathrm{M}$ et al. Role of H2O2 in RET/PTC1 chromosomal rearrangement produced by ionizing radiation in human thyroid cells. 
Cancer Research 201070 4123-4132. (doi:10.1158/0008-5472.CAN09-4336)

79 Marcello MA, Malandrino P, Almeida JF, Martins MB, Cunha LL, Bufalo NE, Pellegriti G \& Ward LS. The influence of the environment on the development of thyroid tumors: a new appraisal. Endocrine-Related Cancer 201421 T235-T254. (doi:10.1530/ERC-14-0131)

80 de Biase D, Cesari V, Visani M, Casadei GP, Cremonini N, Gandolfi G, Sancisi V, Ragazzi M, Pession A, Ciarrocchi A et al. High-sensitivity BRAF, mutation analysis: BRAF V600E is acquired early during tumor development but is heterogeneously distributed in a subset of papillary thyroid carcinomas. Journal of Clinical Endocrinology and Metabolism 201499 E1530-E1538. (doi:10.1210/jc.2013-4389)

81 Flavin R, Jackl G, Finn S, Smyth P, Ring M, O’Regan E, Cahill S, Unger K, Denning K, Jinghuan L et al. RET/PTC rearrangement occurring in primary peritoneal carcinoma. International Journal of Surgical Pathology 200917 187-197. (doi:10.1177/1066896908329593)

82 de Vries MM, Celestino R, Castro P, Eloy C, Maximo V, van der Wal JE, Plukker JT, Links TP, Hofstra RM, Sobrinho-Simoes $\mathrm{M}$ et al. RET/PTC rearrangement is prevalent in follicular Hurthle cell carcinomas. Histopathology 201261 833-843. (doi:10.1111/j.1365-2559.2012. 04276.x)

83 Zhang T, Lu Y, Ye Q, Zhang M, Zheng L, Yin X, Gavine P, Sun Z, Ji Q, Zhu $\mathrm{G}$ et al. An evaluation and recommendation of the optimal methodologies to detect RET gene rearrangements in papillary thyroid carcinoma. Genes, Chromosomes \& Cancer 201554 168-176. (doi:10.1002/gcc.22229)

84 Dinets A, Hulchiy M, Sofiadis A, Ghaderi M, Hoog A, Larsson C \& Zedenius J. Clinical, genetic, and immunohistochemical characterization of 70 Ukrainian adult cases with post-Chornobyl papillary thyroid carcinoma. European Journal of Endocrinology 2012166 1049-1060. (doi:10.1530/EJE-12-0144)

85 Williams ED, Abrosimov A, Bogdanova T, Demidchik EP, Ito M, LiVolsi V, Lushnikov E, Rosai J, Sidorov Y, Tronko MD et al. Thyroid carcinoma after Chernobyl latent period, morphology and aggressiveness. British Journal of Cancer 200490 2219-2224. (doi:10.1038/sj.bjc.6601860)

86 Rhoden KJ, Johnson C, Brandao G, Howe JG, Smith BR \& Tallini G. Real-time quantitative RT-PCR identifies distinct c-RET, RET/PTC1 and RET/PTC3 expression patterns in papillary thyroid carcinoma. Laboratory Investigation 200484 1557-1570. (doi:10.1038/labinvest.3700198)

87 Miki H, Kitaichi M, Masuda E, Komaki K, Yamamoto Y \& Monden Y. ret/PTC expression may be associated with local invasion of thyroid papillary carcinoma. Journal of Surgical Oncology 199971 76-81 discussion 81-82. (doi:10.1002/(SICI)1096-9098(199906)71:2< 76::AID-JSO4>3.0.CO;2-0)

88 Jhiang SM, Sagartz JE, Tong Q, Parker-Thornburg J, Capen CC, Cho JY, Xing S \& Ledent C. Targeted expression of the ret/PTC1 oncogene induces papillary thyroid carcinomas. Endocrinology 1996137 375-378. (doi:10.1210/endo.137.1.8536638)

89 Di Renzo MF, Olivero M, Ferro S, Prat M, Bongarzone I, Pilotti S \& Belfiore A. Costantino A, Vigneri R, Pierotti MA, et al. Overexpression of the c-MET/HGF receptor gene in human thyroid carcinomas. Oncogene 19927 2549-2553.

90 Corvi R, Martinez-Alfaro M, Harach HR, Zini M, Papotti M \& Romeo G. Frequent RET, rearrangements in thyroid papillary microcarcinoma detected by interphase fluorescence in situ hybridization. Laboratory Investigation 200181 1639-1645. (doi:10.1038/labinvest.3780377)

Received 30 October 2014

Revised version received 11 February 2015

Accepted 19 February 2015 